\title{
Does Migration Reshape Expenditures in Rural Households? \\ Evidence from Mexico
}

\author{
J. Edward Taylor \\ University of California, Davis
}

Jorge Mora

El Colegio de Mexico

Key Words: Expenditures, Demand, Migration, Mexico, Remittances

World Bank Policy Research Working Paper 3842, February 2006

The Policy Research Working Paper Series disseminates the findings of work in progress to encourage the exchange of ideas about development issues. An objective of the series is to get the findings out quickly, even if the presentations are less than fully polished. The papers carry the names of the authors and should be cited accordingly. The findings, interpretations, and conclusions expressed in this paper are entirely those of the authors. They do not necessarily represent the view of the World Bank, its Executive Directors, or the countries they represent. Policy Research Working Papers are available online at http://econ.worldbank.org.

The authors are, respectively, Professor of Agricultural and Resource Economics at the University of California, Davis, and Doctoral Candidate at El Colegio de Mexico. Contact: J. Edward Taylor, Department of Agricultural and Resource Economics, University of California, Davis, CA 95616 (jetaylor@ucdavis.edu). Taylor is a member of the Giannini Foundation of Agricultural Economics. 


\section{Non-Technical Summary}

Migration reshapes rural economies in ways that may go beyond the contribution of migrant remittances to household income. Consumption and investment expenditures by migrant-sending households may transmit some of the impacts of migration to others inside and outside the rural economy, and they also may shape the potential effects of migration within the source household. Numerous studies have attempted to quantify the impact of migrant remittances on expenditures in migrant-sending households following one of two approaches. The first asks how migrant remittances are spent. It has the advantage of being simple but the significant disadvantage of ignoring the fungibility of income from migrant and nonmigrant sources. Remittances almost certainly have indirect effects on expenditures via their contribution to households' total budgets. The second uses a regression approach that considers remittances as an explanatory variable, in addition to total income and other controls, in a household expenditure demand system. It has the advantage of enabling one to test whether remittances affect expenditures in ways that are independent of their contribution to total income. However, it does not take into account other ways, besides remittances, in which migration may influence expenditure patterns in households with migrants. It also may suffer from econometric bias resulting from the endogeneity of migration and remittance receipts. The same variables may simultaneously affect both remittances and household expenditures, and unless one controls for this, biased estimates may result. 


\title{
Does Migration Reshape Expenditures in Rural Households? \\ Evidence from Mexico
}

\begin{abstract}
The impact of migration on expenditure patterns in rural migrant-sending households has received considerable attention in the literature because of its ramifications for economic growth and demand linkages in rural economies. A key question that researchers have addressed is what impact, if any, households' receipt of remittance income has on productive investments, which are considered to be a driver of growth in rural areas and a potential creator of local economic alternatives to migration. Empirical research on expenditures in migrant-sending households often has contributed to a pessimistic view of the impact of migration on development in migrant-sending areas. Most studies conclude that remittances are consumed instead of invested and thus are not put to productive uses in migrant-sending areas (for reviews, see Chami, Fullenkamp and Jahjah, 2003; Taylor et al., 1996; Durand and Massey, 1992; and Papademetrious and Martin, 1991). ${ }^{1}$ However, other researchers find the opposite (e.g., Massey, et al., 1987; for a detailed review see Taylor, et al., 1996).
\end{abstract}

Two approaches dominate empirical research on migration and expenditures. The first is based on remittance use surveys, which ask remittance-receiving households what

\footnotetext{
${ }^{1}$ Rempel and Lobdell (1978), reporting on a survey of 50 remittance-use studies for the International Labour Office, concluded that "most of the money remitted is used for increased consumption, education and better housing". Lipton (1980) likewise concluded that investment is a low-priority use of remittances in migrant-sending villages and that "everyday [consumption] needs often absorb 90 percent or more of a village's remittances". One study cited in Chandavarkar (1980:39) concluded that remittances are "frittered away in personal consumption, social ceremonies, real estate, and priceescalating trading".
} 
goods and services they spent their remittances on. These studies suffer from a number of limitations. Most importantly, they ignore the fungibility of household income from diverse sources. The ways in which remittances, themselves, are spent may tell us little about remittances' effect on the array of goods and services that households purchase. When migrants send home remittances, this income becomes part of household budgets and thus may simultaneously alter the complete set of household expenditures. Remittance-use studies make the mistake of assuming that household income is not fungible. Because of this, they provide little insight into the ways in which remittances actually influence expenditure patterns in remittance-receiving households.

A second, more recent set of studies uses an econometric approach, adding remittance income as an explanatory variable in a system of household demand equations. That is, demand is modeled as a function of not only income, prices, and socio-demographic variables but also the amount of remittance income households receive. Examples include Adams (2005, 1998, and 1991) and Alderman (1996). An advantage of this approach is that it is consistent with widely used consumer demand models, which assume that income from diverse sources is pooled into a common household budget constraint. At the same time, it allows for the possibility that migrant remittances have an independent effect on expenditure patterns. For example, a $\$ 1$ increase in income from remittances may have a different effect on expenditures than a $\$ 1$ increase in farm income. Remittances may interact with other variables, including total expenditures and household socio-demographic characteristics, as illustrated clearly in Adams (2005). 
This approach has several disadvantages, as well. First, migration may affect household expenditures in ways that remittances do not adequately capture, as described below. In fact, it is extremely difficult to separate remittance from migration effects on expenditures. Moreover, it is not obvious why one would want to do this. Second, migrant remittances may be endogenous, reflecting migrants' earnings as well as their remittance behavior (e.g., see Lucas and Stark, 1985). For example, a variable like education or information from migrants may affect both household expenditures and remittances. Econometrically, a key question is whether remittances are measured with error, and if so, whether the error is correlated with the errors in the expenditure system. If so, failure to control for the endogeneity of remittances is likely to result in biased estimates of remittance effects on expenditures. Third, empirical studies show that migration is a selective process. ${ }^{2}$ Households that participate in migration and receive remittances differ fundamentally from those that do not (e.g., see Mora and Taylor, 2005). Because of this, it is important to control for the determinants of migration when estimating impacts of migration on household expenditures. The effects of households' selection into or out of migration may be confounded with the effects of remittances on expenditures. For example, a finding that remittances are negatively associated with household investments could signal that households with high propensities to invest have a low propensity to migrate.

\footnotetext{
${ }^{2}$ This does not necessarily imply that migration selects positively with respect to human capital, wealth, or other variables; e.g., see Borjas (1989) and Hatton and Williamson (2004).
} 
We argue and offer empirical evidence that migration reshapes village household expenditure patterns in direct and indirect ways that existing models do not adequately address. The modeling approach we employ controls for the endogeneity of household migration decisions while testing for differences in expenditure patterns between migrant and non-migrant households. We estimate this model for both international and internal migration. The data to estimate the model are from the Mexico National Rural Household Survey of 2003. This survey gathered detailed information on incomes, migration, and expenditures from a nationally representative sample of 1,782 households in rural Mexico.

Findings from the econometric analysis reveal that expenditure patterns differ significantly between migrant and non-migrant households, sometimes in surprising ways. This is true for both international and internal migration. Other things (including total expenditures) being equal, compared with otherwise similar households without migrants, households with international migrants have large marginal budget shares for investments, health, and consumer durables and small marginal budget shares for food and housing. Households with internal migrants have relatively large marginal budget shares for health, housing, services and education and small marginal budget shares for supermarkets, consumer durables, and investments.

\section{Remittances and Expenditures in Migrant Households}

Past research on remittance use offers a partial and possibly distorted view of how remittances influence demand, due to the fungibility of income. Moreover, it often rests 
on arbitrary definitions of what constitutes productive investments. For example, schooling often is absent from the list of productive investments. This probably is because expenditures on educating family members usually do not create direct, immediate employment and income linkages within migrant-sending economies. Housing expenditures are not considered productive investments in many studies, despite their potentially important effects on family health and their direct stimulus to village construction activities. By contrast, expenditures on farm machinery generally are regarded as productive investments, in spite of the fact that machinery is not produced within the village economy and may even displace labor in village production and produce negative income linkages.

Reported use of remittances for productive investments at times can be significant. In their review of studies carried out in Mexico, for example, Durand and Massey (1992) found that the relative share of remittances spent on production, although always under 50 percent, fluctuated considerably from place to place and often reached substantial levels. Remittances enabled many communities to overcome capital constraints to finance public works projects such as parks, churches, schools, electrification, road construction, and sewers (Reichert, 1981; Massey et al., 1987; Goldring, 1990). Other studies report that remittances have been critical to the capitalization of migrant-owned businesses. Escobar and Martinez (1990), for example, found that 31 percent of migrants surveyed in Guadalajara used U.S. savings to set up a business. Massey et al. (1987), in their survey of the same city, put the figure at 21 percent; and in a survey of businesses located in three rural Mexican communities, Cornelius (1990) found that 61 percent were founded with U.S. earnings. A number of 
studies from other world regions echo these findings. (For a detailed review, see Taylor, et al., 1996.)

Under the right circumstances, then, a significant percentage of migrant remittances and savings may be devoted to productive enterprises. Rather than concluding that migration inevitably leads to dependency and a lack of development, it is more appropriate to ask why productive investment occurs in some communities and not in others. Durand and Massey (1992:27) conclude that, in Mexico, "the highest levels of business formation and investment occur in urban communities, rural communities with access to urban markets, or rural communities with favorable agricultural conditions."

Pessimistic findings of past research may be attributable in part to poor research designs that do not consider the direct and indirect ways in which remittances may affect rural household expenditures. Recent empirical models have been designed to overcome this problem.

\section{Estimating Impacts of Migration on Demand}

Most models of household expenditures assume that households allocate their budgets across expenditure categories so as to maximize utility obtained from the consumption of goods and services, either presently or, in the case of investment expenditures, in the future. ${ }^{3}$ With the exception of a nascent empirical literature on intra-

\footnotetext{
${ }^{3}$ This budget may be assumed to be exogenous or fixed, as in the standard consumer model, or it may be an endogenous outcome of household labor allocations and/or production choices, as in an agricultural household model (Singh, Squire and Strauss, 1986). Analysis of investments along with consumption demand generally requires a dynamic formulation of these models, inasmuch as the economic returns from investments are realized in the future.
} 
household resource allocation models, most consumer models assume that households pool their income. This leads them to ignore income-source effects. The solution to such a consumer model is a set of expenditure functions of the following form:

(1) $e_{h i}=f\left(\underline{P_{h}}, Y_{h}, Z_{h}\right)+u_{h i}$

where the subscripts $\mathrm{h}$ and i refer to household and expenditure category, respectively; $e_{h i}$ denotes expenditure on good i by household $\mathrm{h} ; \underline{P_{h}}$ is a vector of prices faced by the household; $Y_{h}$ is household income; $Z_{h}$ represents other variables influencing marginal utilities and constraints on household behavior, and $u_{h i}$ is an error term that is assumed to be approximately normally distributed with mean zero and a variance of $\sigma^{2}$. In the standard consumer model, for a household with K diverse sources of income (possibly including remittances), income is the pooled sum of income from these sources:

(2) $Y_{h}=\sum_{k=1}^{K} y_{h k}$

Combining equations (1) and (2), it is evident that a marginal change in income from a given source $\mathrm{k}$ (say, remittances) has the same effect on expenditures as a marginal change in any other income source:

(3) $\frac{\partial e_{h i}}{\partial y_{h k^{\prime}}}=\frac{\partial f\left(P_{h}, Y_{h}, Z_{h}\right)}{\partial Y_{h}} \frac{\partial Y_{h}}{\partial y_{h k^{\prime}}}=\frac{\partial f\left(P_{h}, Y_{h}, Z_{h}\right)}{\partial Y_{h}}$ 
Other things being equal, an increase in remittances from migrants shifts remittance-receiving households' budget constraints outward by the amount of the remittance transfer. This raises (decreases) the demand for normal (inferior) goods. In this model, the influence of migrant remittances is assumed to be limited to indirect effects operating through total income; income-source effects are ruled out.

Recent studies by Adams (2005, 1998, and 1991), Zarate-Hoyos (2004) and Alderman (1996) add a new explanatory variable to the right-hand-side of Equation 1: household income from migrant remittances $R_{h}$, where $R_{h}$ is also included in $Y_{h}$. That is,

(4) $e_{h i}=f\left(\underline{P_{h}}, E_{h}, Z_{h}, R_{h}\right)+u_{h i}^{\prime}$

Where as in most demand studies, total expenditures $E_{h}$ are used in lieu of income. The marginal effect of a change in remittance income, $y_{h k^{\prime}}$, on household $h$ 's expenditure on good $i$ is thus:

(5) $\frac{\partial e_{h i}}{\partial y_{h k^{\prime}}}=\frac{\partial f \underline{\left(P_{h}, Y_{h}, Z_{h}\right)}}{\partial E_{h}}+\frac{\partial f\left(P_{h}, Y_{h}, Z_{h}\right)}{\partial y_{h k^{\prime}}}$ 
This is the same as $\frac{\partial f\left(P_{h}, Y_{h}, Z_{h}\right)}{\partial E_{h}}$ only if there are no direct effects of remittances on expenditures. In practice, a dummy variable indicating households' receipt of remittances, rather than the level of remittances, is used. Following this approach and including interactions between the remittance-receipt variable and other variables in Equation 4, Adams found evidence that the spending behavior of rural Guatemalan households with remittances was significantly different than that of households without remittances. Specifically, households with remittance income spent less on consumption goods than otherwise similar households without remittance income, dispelling the notion that remittances are "conspicuously consumed." This implies that the second term on the right hand side of Equation 5 is nonzero. Similar results are reported in Adams $(1998,1991)$ and Alderman (1996), using data from other less developed countries.

The finding that the receipt of remittances influences expenditure patterns naturally raises the question, "Why?" Equation 4 suggests two possible explanations. First, the receipt of remittances may correlated with other determinants of demand, i.e., prices $\left(\underline{P_{h}}\right.$, which may include household shadow prices for nontradables and transaction costs for tradables) and/or other variables, $Z_{h}$. Alternatively, both remittances and expenditures may be influenced by variables not included in Equation 4 . The most obvious candidate is migration, itself, which is highly selective on household characteristics that also may influence expenditures. 
The vector of prices, $\underline{P_{h}}$, in equation 4 is not limited to market prices. It also may contain unobserved "shadow prices" for household nontradables (e.g., see Strauss, 1984 and de Janvry, Fafchamps and Sadoulet, 1991). These shadow prices are endogenous and influenced by household decisions, potentially including migration. Remittances are the outcome of household integration with outside labor markets, via migrants, but migration also links village households to new markets, societies and cultures. Family migrants may facilitate households' integration with distant markets for consumption and investment goods, lowering transaction costs and effectively altering prices confronting the household. Investing time in migration is a prerequisite for receiving remittances. The loss of family labor to migration may make family time on the farm more scarce, increasing the opportunity cost of time (or the family "shadow wage"). In a Becker (1965)-type model, a decrease in prices of goods combined with an increase in the shadow wage, other things being equal, would induce the household to substitute purchased for home-produced goods and to shift from more to less time-intensive home produced goods.

Constraints on household expenditures include not only income but also information, uncertainty and risk aversion, and preferences. If migrants provide households with information, this may have various effects on expenditures, for example, by broadening the consumption set, creating a demand for new traits (e.g., nutrition), or altering household production technologies (i.e., "better" ways of producing goods at home). Information from migrants in this way may loosen human capital constraints on 
household production, investment, and consumption activities, while perhaps influencing preferences, as well.

Even if migrants did not contribute income, their contact with an economy and society foreign to the village might influence village preferences and demands. Consumption is shaped, at least in part, by reference groups and identities. As rural farmers are brought into the global economy — both through their participation in wage work and increasing reliance on remittances from other family members, and through their increased consumption of non-local commodities-their expenditure patterns change, reflecting both the influence of new cultural standards and a reorganization of finances within the family farm.

If the household is risk-averse and remittances are not perfectly correlated with other income sources, the effect of remittances on consumption and investments in an uncertain world is likely to be different than the effect of income with different risk profiles. For example, households would be expected to allocate income from a risky source, like crop production, more conservatively than income from remittances, if the latter are viewed as being more certain. Differences in the effects of income from different sources in this case would reflect the influence of risk and uncertainty on household utility from various consumption and investment choices. Even if the variability of migration income is greater than the variability of farm income, income from migration nevertheless may reduce total household income risk through a low (or perhaps negative) correlation with farm income. 
Remittance income may be perceived as more or less transitory than income from other sources. A permanent flow of remittances may encourage households to invest in goods whose use and upkeep require additional purchases in the future (e.g., fuel for a new vehicle). Income from migrants also may be controlled by different household members than income from other sources. In this case, a non-unitary household model might predict differences in marginal expenditures across income sources, reflecting the preferences and influence within the household of those who receive income from a given source (e.g., see McElroy, 1990; Schultz, 1990; Udry, 1996).

\section{The Endogeneity of Migration}

The allocation of family labor to migration generally is a prerequisite to receiving migrant remittances. Migration is highly selective of individuals, households and communities. Variables that "explain" migration also may be correlated with household expenditure patterns. Households with migrants may be fundamentally different from those without migrants with respect to their expenditures as well as their labor allocation. Even if remittances were exogenous (i.e., $R_{h}$ and $u_{h i}^{\prime}$ were uncorrelated in Equation 4), the expected expenditure on good i by a household with migrants (and thus remittances) would be given by:

(6) $E\left(e_{h i} / M_{h i}=1\right)=E f\left(\underline{P_{h}}, E_{h}, Z_{h}, R_{h}\right)+E\left(u_{h i}^{\prime} / M_{h i}=1\right)$ 
That is, expenditures by migrant households are conditional upon the decision to participate in migration $\left(M_{h i}=1\right)$. Conversely, the expected expenditures by nonmigrant households are conditional upon nonmigration. The conditional errors $E\left(e_{h i} / M_{h i}\right)$ cannot be assumed to be zero, because unobserved variables affecting migration may be correlated with expenditures.

In short, three econometric concerns emerge from a review of recent estimates of remittance effects on household expenditures. First, remittances are not predetermined; rather, they are endogenous outcomes shaped by some of the same variables that may influence expenditures, including migration, itself. Second, including remittances in the expenditure equations will not necessarily control for the range of effects that migration may have on expenditures. Third, migration is endogenous. It is shaped by variables that also may influence the ways in which households spend their income. Are households with a high ex-ante probability of migration more or less likely to use their income for productive investments? Are these households more integrated with outside markets for goods as well as for labor, in ways that might affect how they spend their income? In the case of consumption expenditures and investments that are "lumpy," there is an additional econometric issue of censorship; that is, many households have zero expenditure on certain items. Examples of this include housing and other investments and spending on consumer durables. The modeling approach proposed below attempts to address these concerns. 


\section{Empirical Model}

Our application involves a simultaneous-equation model in which the dependent variables, household expenditure shares, are censored by unobserved latent variables influencing the decision to spend income on given consumption and investment goods, and they also depend on the decision of whether or not to participate in migration. Expenditure by household $\mathrm{h}$ on good $\mathrm{i}$ is observed (i.e., $e_{h i}>0$ ) only if the household's total desired expenditure on the item exceeds some threshold. This threshold will depend on the lumpiness of the good (e.g., one cannot buy a car for less than a certain amount) as well as the opportunity cost (the satisfaction or utility that the household would enjoy by spending this threshold amount on some other item). Both the decision to spend income on a specific category of goods and the amount spent depend on the variables in Equation $1\left(\underline{P_{h}}, E_{h}, Z_{h}\right)$, as well as on migration. Assuming that the stochastic errors are approximately normal with zero means and a finite variance-covariance matrix that is constant over all observations - that is, iid - the system of expenditure equations can be estimated using Lee's (1978) generalization of Amemiya's (1974) two-step estimator to a simultaneous-equation model. Lee demonstrated that the estimators resulting from this procedure are asymptotically more efficient than other two-stage estimators, namely, those proposed by Heckman (1978) and Nelson and Olsen (1978). A number of studies employ a censored regression approach to model demand systems without testing for migration effects. These include Heien and Wessells (1990), Shonkwiler and Yen (1999), Lazaridis (2003) and Jabarin (2005). 
In the first stage, a probit is estimated for participation in each expenditure category. The dependent variable in each probit is equal to 1 if $e_{h i}>0$ and zero otherwise. The right-hand variables include $\underline{P_{h}}, E_{h}$ and $Z_{h}$ (defined above), $E_{h}$ is also interacted with $M_{h}$, where $M_{h}=1$ if the household participates in migration and 0 otherwise. $\left(M_{h}\right.$ is endogenous; construction of an instrument for this variable is discussed below). The probits are used to calculate a set of inverse-Mills ratios, one for each expenditure category in which censorship is likely to be a problem:

$$
I M R_{h i}=-\phi\left(X_{h}\right) / \Phi\left(X_{h}\right)
$$

where $\phi\left(X_{h}\right)$ denotes the standard normal density function and $\Phi\left(X_{h}\right)$ denotes the normal distribution function, and $X_{h}$ is a vector containing $\underline{P}_{h}, E_{h}, Z_{h}$ and their interactions with $M_{h}$.

In the second step, the inverse-Mills ratios are included as right-hand variables in the corresponding expenditure equations. We estimated the expenditure system using the Almost Ideal Demand System (AIDS) method, extended to include the migration interactions described above (Deaton and Muellbauer, 1980). Prices were not available for all expenditure categories, most of which are not homogeneous. The unrestricted regressions are of the form:

(8) $e_{h i} / E_{h}=\alpha_{i}+\beta_{1 i} \ln \left(E_{h}\right)+\beta_{2 i} Z_{h}+\beta_{3 i} M_{h}+\beta_{4 i} \ln \left(E_{h}\right) M_{h}+u_{h i}^{\prime}$ 
where $e_{h i} / E_{h}$ is the share of household h's expenditure on good i, and $\alpha_{i}, \beta_{k i}, k=1, \ldots, 4$, are parameters. This functional form displays a number of advantages for our purposes. It is flexible enough to allow expenditure patterns to change with total expenditure level. It permits participation in migration to shift the intercept, the marginal propensity to spend income, and the marginal effect of other variables on expenditures on each category of goods. It also controls for the endogeneity of migration and censorship for some (lumpy) expenditure categories. Finally, it has attractive properties from a theoretical point of view, e.g., restrictions are easily imposed so that it conforms to adding-up, homogeneity, and symmetry properties derived from the standard demand theory (Lazaridis, 2003).

The restricted regression is of the form:

(9) $e_{h i} / E_{h}=\alpha_{i}+\beta_{1 i} \log \left(E_{h}\right)+\beta_{2 i} Z_{h}+u_{h i}^{\prime \prime}$

Because the equation system given by (9) is nested within (8), a test for differences in demand between migrant and nonmigrant households can be implemented by forming the statistic $2\left(L^{R}-L^{U}\right)$, where $L^{R}, L^{U}$ are the values of the log-likelihood function corresponding to the restricted and unrestricted systems, respectively. Under the null hypothesis that demand patterns are the same for migrant and nonmigrant households, this statistic is distributed as $\chi_{d f}^{2}$ with degrees of freedom equal to the number of restrictions in (9). 
Instruments for migration were obtained from probit regressions of $M_{h}$ on household characteristics $Z_{h}$ and the number of household members involved in each migration type (international and internal) in 1990, 12 years prior to the time at which household expenditures are observed. The latter were the key identifying variables used to obtain the migration instruments. The predicted probabilities of migration obtained from these probits, rather than observed migration, were used in the expenditure system estimation.

The system of expenditure equations was estimated jointly for the full household sample using three-stage least squares to exploit the information contained in the crossequation error correlations. To improve efficiency, we estimated the system using iterative three-stage least squares. Both an "unrestricted" and a "restricted" expenditure system were estimated. The unrestricted system includes the migration variable and its interactions with the logarithm of total expenditure $\left(\underline{P_{h}}, E_{h}\right)$. The restricted system omits the migration variable and its interactions. A log likelihood test was used to test whether expenditure patterns are significantly different for migrant and non-migrant households, taking into account both migration and its interactions with the logarithm of total expenditure in the demand system.

\section{Data}

Data to estimate the model are from the Mexico National Rural Household Survey (ENHRUM). This survey provided detailed data on assets, socio-demographic 
characteristics, production, income sources, migration, and expenditures for a representative sample of rural households surveyed in January and February 2003. The sample includes 1,782 households in 14 states. INEGI, Mexico's national information and census office, designed the sampling frame to provide a statistically reliable characterization of Mexico's population living in rural areas, or communities with fewer than 2,500 inhabitants. For reasons of cost and tractability, individuals in hamlets or disperse populations with fewer than 500 inhabitants were not included in the survey. ${ }^{4}$ The result is a sample that is representative of more than 80 percent of the population that the Mexican census office considers to be rural.

To implement the survey, Mexico was divided into five regions, reflecting INEGI's standard regionalization of the country: Center, South-Southeast, West-Center, Northwest, and Northeast. The survey was designed to be representative both nationally and regionally. Data from this survey make it possible to quantify migration and remittances at the household level, as well as to test for influences of these variables on household consumption and investment expenditures.

Detailed data were gathered on migration in 2002 by the household head, the spouse of the household head, all other individuals living in the household, and all sons and daughters of either household head, regardless of where they resided at the time of the survey. Twenty-six percent of households in the sample had at least one internal migrant in 2002; they averaged 2.7 internal migrants each. Sixteen percent participated

\footnotetext{
${ }^{4}$ The percentage of the population of Mexico that lives in hamlets of less than 500 people is no more than
} 
in international migration, with an average of 2.2 international migrants each. Remittances from international migrants are an important income source, comprising an average of 11 percent of household total income. Although the number of internal migrants is higher than the number of international migrants, remittances from internal migrants represent a smaller share of household total income-1.7 percent.

Different types of expenditures have different periodicity, and this was taken into account when gathering expenditure information on the survey. Separate sections of the survey form were designed for annual expenditures (household durable goods, housing investments, farm machinery, taxes, health, education, etc.) and monthly and weekly expenditures (utilities, consumption expenditures in markets, butcher shops, from traveling vendors, etc.). For intermittent expenditures (e.g., at butcher shops, tortillerias, markets, etc.), households were asked whether or not they spent money on a given good at some time in 2002, and if so how often, where, and how much each time. Consumption of home-produced goods (e.g., maize) was calculated as output minus sales minus intermediate use (e.g., use of maize as animal feed).

Expenditure data from the survey were aggregated into three consumption categories, four types of investment, and one "other" (miscellaneous) expenditure category (Table 1). The consumption categories include food, except for that purchased in supermarkets; consumer durables (furniture, appliances, etc.); and expenditures in supermarkets. Expenditures in supermarkets were isolated from expenditures on other 
nondurables because of their increasing importance in Latin America and elsewhere; see Reardon and Berdegué (2002). ${ }^{5}$ The investment categories include health, education, housing and other investments (hereafter referred to simply as "investments"). The category of "other" is constituted primarily of expenditures on miscellaneous services. (In the rest of this paper we refer to this category simply as "services.") These consumption and investment categories are exhaustive; that is, they add up to total household expenditures. There is a high degree of congruity between our total expenditure and total income estimates. Total income was estimated separately from expenditures, using detailed data on household-farm production, wage work and migration. ${ }^{6}$ Average per-capita income in the full sample was 15,766 pesos, while average total expenditure per capita was 14,965 pesos. $^{7}$

Household expenditures are summarized in Table 2. The top panel presents average budget shares for each household group. The bottom panel compares expenditure levels and total expenditures. The largest expenditure shares for nonmigrant households are for food (0.42), services (0.18) and consumer durables $(0.10)$. Approximately $23 \%$ of expenditures by nonmigrant households were on health,

\footnotetext{
${ }^{5}$ The expenditure module for the survey was designed so as to avoid double-counting of expenditures on durables and nondurables purchased in supermarkets. Thus, the sum of these three expenditure categories represents total expenditure on consumption goods.

${ }^{6}$ We calculated net incomes from twelve sources: crop, livestock, nonagricultural (composed of handicrafts, village nonfarm enterprises, small-scale food processing, and various other home-based production activities), commerce, service, natural resource extraction, wage labor (agricultural and nonagricultural), and migration (internal and international), as well as from public transfers (PROCAMPO subsidies for basic grain producers and PROGRESA welfare payments). This list of incomes is exhaustive; the sum of income from the twelve sources equals household total net income.

${ }^{7}$ The exchange rate at the time of the survey was approximately 10 pesos per U.S. dollar.
} 
education, housing and other investments. The largest of these was education (0.09) and other investments (0.06), followed by health (0.05) and housing (0.04).

Compared with households that did not have migrants, households with international migrants have a larger share of total expenditures on food (0.37), services (0.27), consumer durables (0.08), investments (0.07), and health (0.07); smaller shares on supermarkets (0.03) and education (0.06); and similar shares on housing (0.03). Internal migrant households spend larger shares on food (0.41), services (0.26), consumer durables (0.07) and education (0.07); lower shares on health (0.06) and supermarkets (0.05); and a similar share on housing (0.03).

The bottom panel of Table 2 reveals that, in absolute terms, households with international migrants have per-capita total expenditures that are 26 percent higher than those of nonmigrant households. They spend more income on consumer durables and food as well as on investments, health, and services. By contrast, internal migrant households have per-capita total expenditures that are 2 percent lower than those of nonmigrant households, and their expenditures on most categories of goods are lower, as well. A notable exception is investments, on which internal migrant households spend an average of 44 percent more than nonmigrant households.

It is not clear whether these differences in expenditure levels or shares are due to household migration status or whether they are the result of differences in other variables, including total expenditures and socio-demographic characteristics. For example, even 
though international migrant households spend more income on consumer goods, their marginal budget share for these goods may be either higher or lower than that of nonmigrant households. It is possible that increases in income and expenditures result in greater increases in consumption expenditures in nonmigrant than in migrant households. Econometric analysis is required to compare expenditure patterns of migrant households with those of otherwise similar households without migrants.

Household migration and socio-demographic variables hypothesized to influence expenditures (the $Z_{h}$ in our econometric model) are summarized for each of the three household groups in Table 3. The household socio-demographic characteristics in our model include: household size (averaging 4.05 for nonmigrant households, 3.80 for households with international migrants, and 3.75 for households with internal migrants); number of children ( $0.64,0.37$ and 0.36 , respectively); age of the household head (44, 56 and 59 years); landholdings (4.42, 7.69, and 4.57 hectares, respectively); the education of the household head (5.17, 3.30 and 2.93 years); and the number of household members at each schooling level $(6,9$, and 10 or more years of completed schooling). The model also includes two indicators of access to outside markets. The first is an index of the frequency of transport availability between the village and commercial centers with which villagers transact. To construct the frequency of transport variable, we (a) created a list of commercial centers (node) with which each village interacted; (b) constructed an index of frequency of regularly scheduled transportation between the village and each of these nodes, ranging from 0 (less than one trip per day) to 3 (more than six trips per day); and (c) summed this frequency index across commercial nodes. The higher the value of 
this index, the greater the frequency of transport and number of outside communities with which the village is linked via regularly scheduled transportation. Table 3 shows that on average migrant households have somewhat greater access to transport, as measured by this variable, than nonmigrant households. The second market-access variable is a dummy variable equal to 1 if the village in which the household is situated is inaccessible to outside markets during weather shocks and 0 if the village maintains access to outside markets throughout the year. There is little difference in the average for this variable across the three household groups. Finally, the model includes a set of 4 regional dummy variables (northwest, northeast, central, and west-central; the default region is the southeast).

\section{Results}

The results of probit regressions used to obtain the migration instruments are summarized in Appendix 1. The migration probit results suggest that the 1990 migration instruments have significant predictive power for explaining the potentially contaminated 2002 migration variables. The results of the probit regressions used to obtain inverseMills ratios to correct for censorship in the demand-system estimation appear in Appendix 2. Although these are not the primary focus of this paper, they confirm that the $\log$ of total expenditures and some demographic variables have a statistically significant effect on the probability of observing household expenditures for all categories of goods. The frequency of transport variable, a proxy for the cost of transacting with outside markets, is also positive and significant in most cases. The international migration instrument is significant in four of the seven included expenditure equations, and the 
interaction term involving this migration variable and (the log of) total expenditure is also significant in the case of investments. The internal migration variable is statistically significant in two of the expenditure probits, and the interaction between this variable and total expenditure is also significant in the supermarkets equation.

The results of the three-stage least squares estimation of the unrestricted expenditure system using Lee's estimator appear in the Table 4. A likelihood ratio test easily rejects the null hypothesis that the effects of all migration interaction terms are zero for both migration types. ${ }^{8}$

The regression results reveal that both types of migration influence expenditure patterns in two ways. First, migration significantly shifts the intercept of the expenditure equation in some cases (e.g., international migration in the equations for expenditure shares of food, consumer durables, education, and investments; and internal migration in the equations for food, consumer durables, and investments). Second, it alters the marginal propensity to consume, as reflected in the parameters multiplying the migrationexpenditure interaction terms. (These are significant for international migration in the equations for expenditures on food, consumer durables, education and investments and for internal migration in the equations for food, consumer durables and investments.)

The central question of this paper is: "How does migration influence household expenditures, other things being equal?" Table 5 attempts to answer this question by 
reporting marginal budget shares on each expenditure type for households without migrants, households with international migrants, and households with internal migrants. These were obtained from the estimated unrestricted demand system given in equation 8 . The general formula for the marginal budget shares is:

$$
\partial e_{h i} / \partial E_{h}=\hat{\alpha}_{i}+\left(\hat{\beta}_{1 i}+\hat{\beta}_{4 i} M_{h}\right)\left(1+\ln \left(E_{h}\right)\right)+\hat{\beta}_{2 i} Z_{h}+\hat{\beta}_{3 i} M_{h}
$$

In this formula, "^" refers to an estimated parameter. The marginal budget share for nonmigrants is evaluated by setting the migration variables $M_{h}$ in Equation 10 equal to zero, thereby eliminating all migration effects from the system. ${ }^{9}$ The marginal budget shares for a given class of migrants (international or domestic) were calculated by setting the corresponding migration variables equal to 1.0 and the migration terms for the other migration class to 0 . All other variables in the system were set equal to their means. For each household type, the marginal budget shares add up to 1.0.

It is important to keep in mind that the econometric analysis makes it possible to compare marginal budget shares between households with migrants and otherwise similar households without migrants. The findings reported in Table 5 control for all of the explanatory variables included in the expenditure system and described in Table 3.

\footnotetext{
${ }^{8}$ The $\chi^{2}$ statistic (degrees of freedom) corresponding to the null hypothesis that all migration effects are nil is equal to $156.12(28)$, significant at well below the .01 level.
} 
Marginal budget shares for nonmigrant households, other things being equal, are highest for food (0.38), services (0.16), consumer durables (0.12) and investments ( 0.10$)$, followed by housing (0.07), education $(0.06)$, supermarkets $(0.06)$ and health $(0.04$; see Column A in Table 5). These marginal budget shares are the baseline for determining the impact of international and internal migration on household expenditure patterns, controlling for the variables in Table 3.

Households with international migrants have a considerably larger marginal budget share for investments $(0.21$, compared with 0.10$)$ than otherwise similar nonmigrant households (see Column B of Table 5). Controlling for other variables in the equation system, including total expenditures, households with U.S. migrants spend 11 cents more of their marginal dollar on investments than do households without migrants. The marginal budget share for consumer durables is also higher in U.S. migrant households $(0.22$, compared with 0.12$)$. Other things being equal, marginal budget shares are higher in U.S. migrant households than in nonmigrant households for services (0.23, compared with 0.16). Marginal budget shares for food, supermarkets, education and housing are lower in U.S. migrant households than in otherwise similar nonmigrant households.

Households with internal migrants have a marginal budget share for investments that is lower than that of nonmigrant households (0.06, compared with 0.10$)$. However,

\footnotetext{
${ }^{9}$ The restricted regressions were not used for this purpose because, given the rejection of the null hypothesis that the effect of the migration terms is zero, the restricted parameter estimates for other variables in the system are likely to be biased.
} 
marginal budget shares in internal migrant households are larger for services $(0.30$ compared with 0.16$)$, health (0.06 compared with 0.04$)$ and housing (0.08 compared with 0.07). Households with internal migrants have a considerably lower marginal budget share for consumer durables, supermarkets, and investments.

These differences in marginal budget shares result in sharply different levels of expenditures on specific items for migrant and nonmigrant households. Holding other variables, including total expenditures, constant, households with international migrants spend 110 percent more of their income on investments, 85 percent more on consumer durables, 38 percent more on services, 2 percent more on health and less on food, housing, education and supermarkets. Internal migrants spend 28 percent more income on health, 87 percent more on services, 3 percent more on education, 9 percent more on housing and less on consumer durables, supermarkets and investments than otherwise similar households without migrants. The international migration group spends 62 percent less on housing than nonmigrant households with similar incomes and sociodemographic characteristics. In short, if households with international migrants appear to spend a large amount of their income on consumption and housing, this is not because of their migration status; rather, it is due to their higher total income and other characteristics that differentiate migrant and nonmigrant households.

The inverse-Mills ratio is significant in four of the demand equations, those for supermarkets, health, education and investments. These categories include a high percentage of zero expenditures $(78 \%, 37 \%, 42 \%$ and $47 \%$, respectively). For the other 
categories, censorship does not appear to be a significant concern when estimating expenditure demands.

\section{Conclusions}

In this paper we have presented an empirical model to test for and quantify differences in expenditure demands between migrant and nonmigrant households using new household data from rural Mexico. The modeling approach we propose is more general than standard consumer models, remittance-use studies, and recent work extending consumer models by including direct remittance effects. It controls for both censorship in demands and the endogeneity of migration while offering a comprehensive test of migration's effects on expenditure patterns. Our findings indicate that migration reshapes household demands in ways that are independent of total income. Three key insights emerge from this analysis.

First, migration has complex effects on household expenditures. Past studies, which focus on remittance use or include remittances as explanatory variables in household demand models, capture one (albeit potentially important) component of these migration effects. Migration, in addition to contributing to household income, links village households to new markets, societies and cultures; it may induce changes in consumption technologies and induce a substitution of purchased for home-produced goods in response to lost labor and other effects; and it may alter households' information set, risk profile, and preferences in ways that affect marginal utilities of consumption and 
investment. In practice, it is difficult to identify remittance effects distinct from migration effects on expenditures. No attempt is made to do so in this paper.

Second, migration, like expenditures, is an endogenous choice. Studies that fail to control for the endogeneity of migration (or remittances) risk yielding parameter estimates that are biased and potentially misleading.

Third, as noted by other researchers, it is critical to control for other household characteristics, including total expenditures, when studying the expenditure effects of migration. Migration influences expenditures directly as well as indirectly, via its interactions with total expenditures and other household variables. For example, a simple comparison of households with and without migrants reveals that the former spend more income on housing, consumption, and investments. However, migrant households also have higher income than nonmigrant households, on average, and their socio-demographic characteristics differ, as well. It is not clear, a priori, whether differences in average expenditures between migrant and nonmigrant households are due to migration or to these differences in income and other variables.

The findings from our econometric analysis reveal that, compared with otherwise similar households without migrants, as total expenditures in households with migrants increase, the share of income used for investments also increases, while the share spent on consumption falls. This is especially true for international migration. This finding does not support the view that households with migrants disproportionately spend their 
income on consumption. It is consistent with the findings reported by Adams (2005) based on a different modeling approach and data from rural Guatemala.

An overarching conclusion of this research is that criticisms of migration for not stimulating productive investments may be misplaced; they may be more a result of modeling and data limitations than actual differences in expenditure patterns between migrant and nonmigrant households. As rural incomes increase, expenditure patterns change. This is true regardless of whether the income gains are from migration or other sources. The key question that should be of interest to researchers and policy makers is whether expenditure patterns change differently for households that participate in migration, and if so, why. This requires a more complex modeling approach than has been used in past research exploring the impacts of remittances on expenditures. Migration's potential impacts include influences besides those of remittances; expenditure patterns in migrant households must be compared with those in otherwise similar households without migrants while controlling for the endogeneity of migration choices. Our findings reveal that migration does indeed significantly influence expenditure patterns in rural areas, but not in the ways that most past studies of remittance use predict. In particular, the propensity to invest appears to be considerably larger for households with migrants. 
Table 1. Expenditure Categories

\begin{tabular}{|l|l|l|}
\hline Category & \multicolumn{1}{|c|}{ Description } & Examples \\
\hline Food & Purchased food & $\begin{array}{l}\text { Tortillas, meat, milk, } \\
\text { vegetables, fruit } \\
\text { Food from own agricultural } \\
\text { production (e.g. maize) }\end{array}$ \\
\hline Durables & $\begin{array}{l}\text { Consumer goods } \\
\text { durables }\end{array}$ & Furniture, clothing, toys \\
\hline Supermarkets & $\begin{array}{l}\text { Any expenditure in } \\
\text { supermarkets }\end{array}$ & $\begin{array}{l}\text { Any kind of good purchased in } \\
\text { supermarkets }\end{array}$ \\
\hline Health & Health expenses & $\begin{array}{l}\text { Hospitalization, doctor fees, } \\
\text { medicine }\end{array}$ \\
\hline Education & Educational expenses & $\begin{array}{l}\text { Uniforms, transport, } \\
\text { registration fees, school } \\
\text { supplies, accommodations }\end{array}$ \\
\hline Housing & $\begin{array}{l}\text { Housing expenses and } \\
\text { house repairs }\end{array}$ & $\begin{array}{l}\text { Annual payment for housing } \\
\text { (rent, mortgage) and house } \\
\text { construction or repair }\end{array}$ \\
\hline Investments & $\begin{array}{l}\text { Annual value of new } \\
\text { productive assets } \\
\text { purchased and repair of } \\
\text { old assets }\end{array}$ & $\begin{array}{l}\text { Purchase of farm machinery, } \\
\text { farm tools, machinery } \\
\text { refurbishment and repair }\end{array}$ \\
\hline Other & $\begin{array}{l}\text { Household services } \\
\text { Transport }\end{array}$ & $\begin{array}{l}\text { Electricity, gas, water, } \\
\text { telephone, passenger } \\
\text { transportation (except for } \\
\text { schooling), gasoline }\end{array}$ \\
\hline
\end{tabular}


Table 2. Average Budget Shares, Expenditure Levels, and Total Expenditures, by Household Migration Status

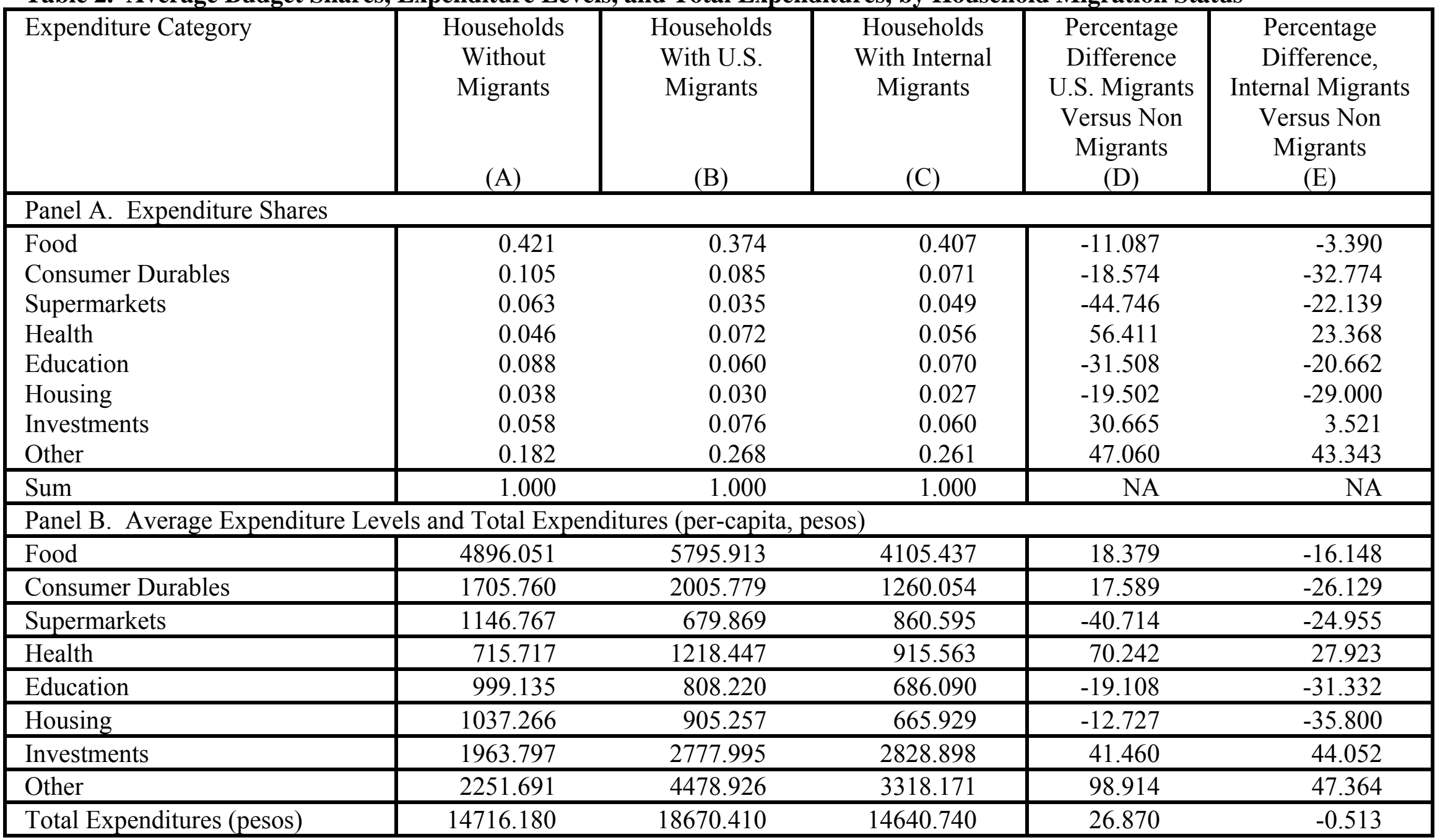

Source: Analysis of ENHRUM data 
Table 3. Means and Standard Deviations of Explanatory Variables in the Expenditure System, by Household Migration Status

\begin{tabular}{|c|c|c|c|c|c|c|}
\hline \multirow[t]{2}{*}{ Variable } & \multicolumn{2}{|c|}{ Households Without Migrants } & \multicolumn{2}{|c|}{$\begin{array}{c}\text { Households With } \\
\text { International Migrants }\end{array}$} & \multicolumn{2}{|c|}{$\begin{array}{c}\text { Households with Internal } \\
\text { Migrants }\end{array}$} \\
\hline & Mean & SD & Mean & SD & Mean & SD \\
\hline Household size & 4.049 & 1.954 & 3.795 & 2.011 & 3.748 & 1.919 \\
\hline Number of children & 0.636 & 0.932 & 0.372 & 0.759 & 0.366 & 0.770 \\
\hline Age of Household head & 43.801 & 15.012 & 56.271 & 13.129 & 59.441 & 14.067 \\
\hline $\begin{array}{l}\text { Schooling of Household } \\
\text { head }\end{array}$ & 5.168 & 3.870 & 3.302 & 3.043 & 2.928 & 3.101 \\
\hline $\begin{array}{l}\text { Number of household } \\
\text { members with six } \\
\text { years of schooling }\end{array}$ & 1.646 & 1.368 & 2.708 & 1.516 & 2.450 & 1.482 \\
\hline $\begin{array}{l}\text { Number of household } \\
\text { members with nine } \\
\text { years of schooling }\end{array}$ & 0.746 & 0.987 & 1.021 & 1.221 & 0.888 & 1.161 \\
\hline $\begin{array}{l}\text { Number of household } \\
\text { members with ten or } \\
\text { more years of } \\
\text { schooling }\end{array}$ & 0.402 & 0.822 & 0.417 & 0.843 & 0.496 & 0.933 \\
\hline Landholdings & 4.416 & 26.330 & 7.692 & 32.184 & 4.571 & 10.696 \\
\hline Frequency of Transport & 7.873 & 5.990 & 8.375 & 5.211 & 9.300 & 5.990 \\
\hline $\begin{array}{l}\text { Inaccessibility During } \\
\text { Weather Shocks } \\
\text { (Dummy) }\end{array}$ & 0.127 & 0.334 & 0.146 & 0.354 & 0.156 & 0.363 \\
\hline
\end{tabular}

\section{Source: Analysis of ENHRUM data}


Table 4. Results of Three-Stage Least Squares Estimation of Expenditure System Using Lee's Estimator

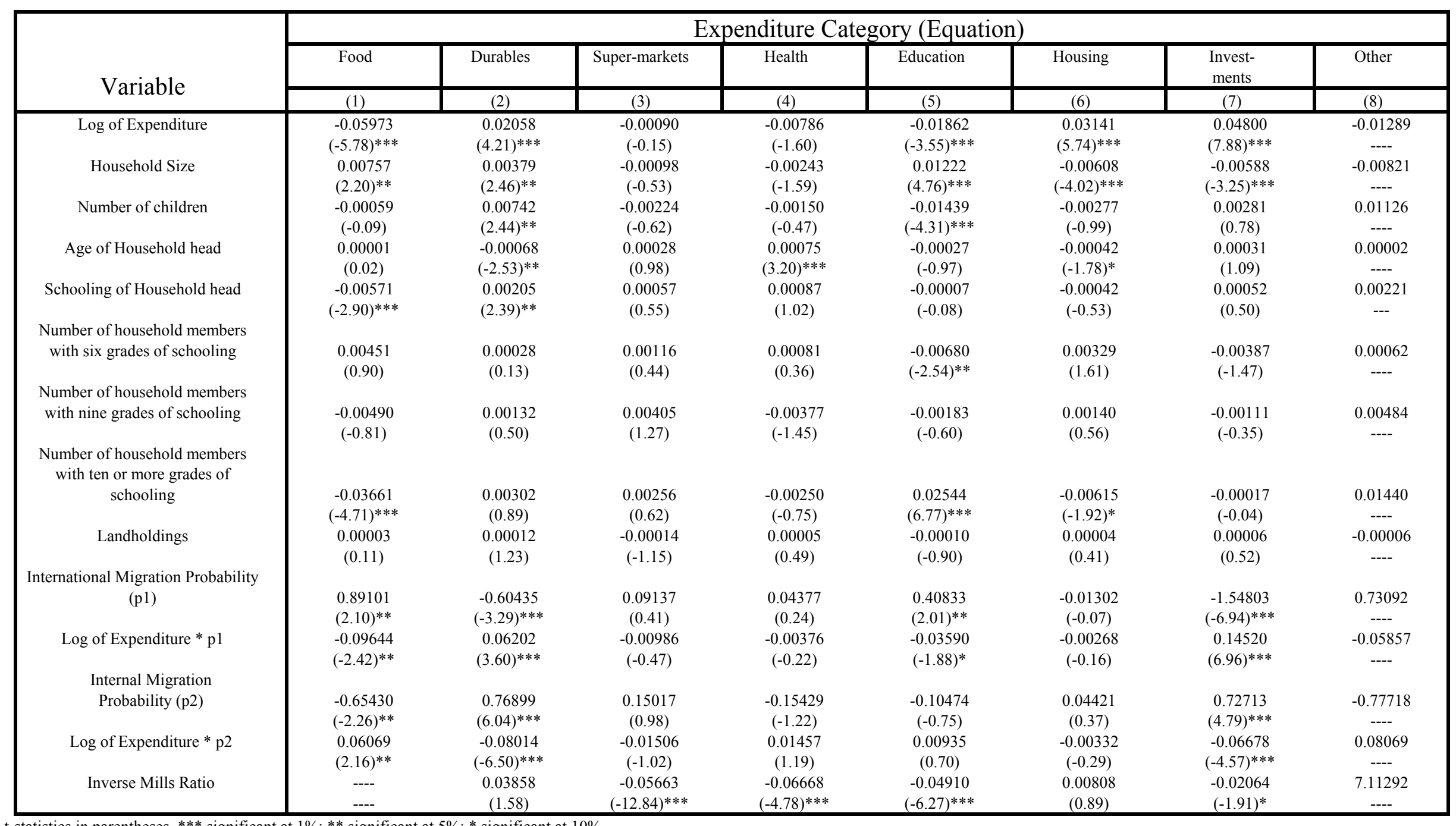

t-statistics in parentheses, ${ }^{* * *}$ significant at $1 \% ;{ }^{* *}$ significant at $5 \% ; *$ significant at $10 \%$ 
Table 5. Comparison of Marginal Budget Shares and Expenditure Levels by Household Migration Status

\begin{tabular}{|l|c|c|c|c|c|}
\hline $\begin{array}{c}\text { Expenditure } \\
\text { Category }\end{array}$ & $\begin{array}{c}\text { Households } \\
\text { Without } \\
\text { Migrants }\end{array}$ & $\begin{array}{c}\text { Households } \\
\text { With U.S. } \\
\text { Migrants }\end{array}$ & $\begin{array}{c}\text { Households } \\
\text { With } \\
\text { Internal } \\
\text { Migrants }\end{array}$ & $\begin{array}{c}\text { Percentage } \\
\text { Difference, } \\
\text { U.S. } \\
\text { Migrants } \\
\text { Versus No } \\
\text { Migrants } \\
\text { (D) }\end{array}$ & $\begin{array}{c}\text { Percentage } \\
\text { Difference, } \\
\text { Internal } \\
\text { Migrants } \\
\text { Versus No } \\
\text { Migrants } \\
\text { (E) }\end{array}$ \\
\hline Food & (A) & $(\mathrm{B})$ & $(\mathrm{C})$ & -54.484 & -0.485 \\
Durables & 0.384 & 0.175 & 0.382 & 84.730 & -80.715 \\
Supermarkets & 0.122 & 0.225 & 0.023 & -35.940 & -36.899 \\
Health & 0.059 & 0.038 & 0.037 & -2.037 & 27.636 \\
Education & 0.043 & 0.044 & 0.055 & -2.145 & 3.180 \\
Housing & 0.060 & 0.059 & 0.062 & -62.363 & 9.045 \\
Investments & 0.070 & 0.026 & 0.076 & 109.625 & -35.111 \\
Other & 0.099 & 0.207 & 0.064 & 38.366 & 87.697 \\
\hline Sum & 0.164 & 0.226 & 0.307 & 38.366 \\
\hline
\end{tabular}




\section{REFERENCES}

Adams, Richard H.. 2005. "Remittances, Household Expenditure and Investment in Guatemala." World Bank Policy Research Working Paper No. 3532. http://ssrn.com/abstract $=695362$ (March).

. 1998. "Remittances, Investment and Rural Asset Accumulation in Pakistan." Economic Development and Cultural Change 47:155-73.

. 1991. "The Economic uses and Impact of International Remittances in Rural Egypt." Economic Development and Cultural Change 39:695-722.

Adams, R.H. and H. Alderman. 1992. "Sources of Inequality in Rural Pakistan: A Decomposition Analysis." Oxford Bulletin of Economics and Statistics 54(4):591-608.

Alderman, H. 1996. "Saving and Economic Shocks in Rural Pakistan." Journal of Development Economics 51:343-365.

Amemiya, T. 1974. "Multivariate Regression and Simultaneous Equations Models When the Dependent Variables are Truncated Normal." Econometrica 42:999-1012.

Becker, Gary. 1965. "A Theory of the Allocation of Time." The Economic Journal, 75:493-517.

Borjas, G. 1989. "Immigrant and Emigrant Earnings: A Longitudinal Study." Economic Inquiry 27(1):21-37 (January).

Chami, R., C. Fullenkamp and S. Jahjah. 2003. "Are Immigrant Remittance Flows a Source of Capital for Development?" International Monetary Fund (IMF) Working Paper 03/189. Washington DC. 
Chandavarkar, A.B. 1980. "Use of Migrants' Remittances in Labor-exporting Countries.” Finance and Development 17:36-44.

Cornelius, Wayne. 1990. Labor Migration to the United States: Development Outcomes and Alternatives in Mexican Sending Communities. Washington, D.C.: Commission for the Study of International Migration and Cooperative Economic Development.

Deaton, Angus, and John Muellbauer. 1980. “An Almost Ideal Demand System," American Economic Review, 70(3), 313-326 (June).

De Janvry, A., M. Fafchamps, and E. Sadoulet. 1991. "Peasant Household Behavior with Missing Markets: Some Paradoxes Explained.” The Economic Journal 101:1400-1417.

Durand, Jorge, and Douglas S. Massey. 1992. "Mexican Migration to the United States: A Critical Review." Latin American Research Review 27:3-42.

Escobar, Agustin and Maria de la O. Martinez. 1990. Small-scale Industry and International Migration in Guadalajara, Mexico. Working Paper No. 53. Washington, DC: Commission for the Study of International Migration and Cooperative Economic Development.

Goldring, Luin. 1990. Development and Migration: A Comparative Analysis of Two Mexican Migrant Circuits. Washington, D.C.: Commission for the Study of International Migration and Cooperative Economic Development.

Heckman, J. 1978. "Dummy Endogenous Variables in a Simultaneous Equation System." Econometrica 46:931-959.

Hatton, T.J. and J.G. Williamson. 2004. International Migration in the Long-Run: Positive Selection, Negative Selection and Policy. Cambridge, MA: National Bureau of Economic Research, NBER Working Paper \#10529 (http://www.nber.org/papers/w10529). 
Heien, D. and Wessells, C. R. 1990. "Demand systems estimation with microdata: a censored regression approach. Journal of Business and Economic Statistics, 8, 365-71.

Jabarin, Amer S. 2005. Estimation of meat demand system in Jordan: an almost ideal demand system, International Journal of Consumer Studies, 29, 232-238.

Lazaridis,P. 2003. Household Meat Demand in Greece: A Demand Systems Approach Using Microdata. Agribusiness, 19(1), 43-59.

Lee, Lung-Fei. 1978. "Simultaneous Equation Models with Discrete and Censored Dependent Variables.” In Manski, P. and McFadden, D., eds., Structural Analysis and Discrete Data with Econometric Applications. Cambridge, MA: MIT Press.

Lipton, Michael. 1980. "Migration from Rural Areas of Poor Countries: The Impact on Rural Productivity and Income Distribution.” World Development 8:10-20.

Lucas, R.E.B. and O. Stark. 1985. "Motivations to Remit: Evidence from Botswana." Journal of Political Economy, 93(5):901-918.

Mora, J. and J.E. Taylor. 2005. Determinants of Migration, Destination and Sector Choice: Disentangling Individual, Household and Community Effects. In Ça-glar Özden and Maurice Schiff, Eds., International Migration, Remittances, and the Brain Drain. New York: Palgrave Macmillan. 2005.

Massey, D. S. 1984. "The Settlement Process among Mexican Migrants in the United States: New Methods and Findings." Immigration Statistics: A Story of Neglect, ed. D. Levine, K. Hill, and R. Warren. Washington, DC: National Academy Press.

Massey, D.S. and E. Parrado. 1994. "Migradollars: The Remittances and Savings of Mexican Migrants to the United States." Population Research and Policy Review 13(1):3-13. 
Massey, D. S., J. Arango, G. Hugo, A. Kouaouci, A. Pellegrino, and J.E. Taylor. 1998. Worlds in Motion: Understanding International Migration at the End of the Millennium. Oxford: Clarendon.

Massey, Douglas S., Rafael Alarcón, Jorge Durand, and Humberto González. 1987. Return to Aztlan: The Social Process of International Migration from Western Mexico. Berkeley and Los Angeles: University of California Press.

McElroy, Marjorie B. 1990. "The Empirical Content of Nash- Bargained Household Behavior." The Journal of Human Resources, XXV(4):559-583.

Nelson, F.D. and L. Olson. 1978. "Specifications and Estimation of a Simultaneous Equation Model with Limited Dependent Variables." International Economic Review 19:695-710.

Papademetriou, Demetrios G. and Philip L. Martin, eds. 1991. The Unsettled Relationship: Labor Migration and Economic Development. New York: Greenwood Press.

Thomas Reardon and Julio A. Berdegué. 2002. "The Rapid Rise of Supermarkets in Latin America: Challenges and Opportunities for Development.” Development Policy Review 20 (4): 371388.

Reichert, Joshua S. 1981. "The Migrant Syndrome: Seasonal U.S. Wage Labor and Rural Development in Central Mexico." Human Organization 40:56-66.

Rempel, H. and R. Lobdell. 1978. "The Role of Urban-to-Rural Remittances in Rural Development.” Journal of Development Studies 14:324-41.

Schultz, T.P. 1990. "Testing the Neoclassical Model of Family Labor Supply and Fertility." Journal of Human Resources 25(4):599-634. 
Shonkwiler, J.S. and Yen, S.T. 1999. Two-step estimation of a censored system of equations, American Journal of Agricultural Economics, 81, 972-82.

Singh, I., L. Squire, and J. Strauss. 1986. An Overview of Agricultural Household Models-The Basic Model: Theory, Empirical Results, and Policy Conclusions, in Agricultural Household Models, Extensions, Applications and Policy, eds., I. Singh, L. Squire, and J. Strauss (The World Bank and the Johns Hopkins University Press, Baltimore), pp.17-47.

Strauss, John. 1986. "Appendix: The Theory and Comparative Statics of Agricultural Household Models: A General Approach.” In Inderjit J. Singh, Lyn Squire and John Strauss (eds.), Agricultural Household Models_Extensions, Applications and Policy. Baltimore: The Johns Hopkins University Press.

Taylor, J. Edward, D.S. Massey, J. Arango, G. Hugo, A. Kouaouci, and A. Pellegrino. 1996. “International Migration and Community Development.” Population Index 62(3):397-418 (Fall).

Udry, Christopher. 1996. Gender, Agricultural Production, and the Theory of the Household. The Journal of Political Economy, Vol. 104, No. 5:1010-1046.

Zarate-Hoyos, A. 2004. Consumption and Remittances in Migrant Households: Toward a Productive Use of Remittances, Contemporary Economic Policy, 22(4), 555-565. 


\section{Appendix 1}

\section{Results of Probit Regressions for Migration Instruments}

\begin{tabular}{|c|c|c|}
\hline Variable & International Migration & Internal Migration \\
\hline \multirow[t]{2}{*}{ Household Size } & 0.1191 & 0.1913 \\
\hline & $(7.70) * * *$ & $(13.08)^{* * *}$ \\
\hline \multirow[t]{2}{*}{ Schooling of Household head } & -0.0367 & -0.0139 \\
\hline & $(-2.67) * * *$ & $(-1.07)$ \\
\hline \multirow[t]{2}{*}{ Age of Household head } & 0.0838 & 0.0263 \\
\hline & $(4.52)^{* * *}$ & $(1.62)$ \\
\hline \multirow[t]{2}{*}{ Age of Household head squared } & -0.0007 & 0.0000 \\
\hline & $(-4.46)^{* * *}$ & $(-0.17)$ \\
\hline \multirow[t]{2}{*}{ Number of children } & -0.0243 & -0.1551 \\
\hline & $(-0.47)$ & $(-3.28)^{* * *}$ \\
\hline \multirow[t]{2}{*}{ Landholdings } & 0.0017 & -0.0018 \\
\hline & $(1.32)$ & $(-0.72)$ \\
\hline \multirow[t]{2}{*}{ Wealth Index } & 0.1569 & -0.0347 \\
\hline & $(5.57)^{* * *}$ & $(-1.34)$ \\
\hline \multirow[t]{2}{*}{ Wealth Index-squared } & -0.0057 & -0.0095 \\
\hline & $(-0.56)$ & $(-1.16)$ \\
\hline \multirow[t]{2}{*}{ Inaccessibility During Weather Shocks (Dummy) } & 0.3604 & 0.0622 \\
\hline & $(2.89)^{* * *}$ & $(0.54)$ \\
\hline \multirow[t]{2}{*}{ Nonagricultural Enterprise in Village (Dummy) } & -0.0193 & -0.0258 \\
\hline & $(-0.19)$ & $(-0.28)$ \\
\hline \multirow[t]{2}{*}{ Frequency of Transport } & -0.0029 & 0.0177 \\
\hline & $(-0.37)$ & $(2.60)^{* * *}$ \\
\hline \multirow{2}{*}{$\begin{array}{l}\text { Number of Family Members at U.S. Migrant Destination } \\
\text { in } 1990\end{array}$} & & \\
\hline & $\begin{array}{c}0.6280 \\
(75) * * *\end{array}$ & 0.1424 \\
\hline \multicolumn{3}{|l|}{ Number of Family Members at Internal Migrant } \\
\hline \multirow[t]{2}{*}{ Destination in 1990} & 0.0009 & 0.2186 \\
\hline & $(0.01)$ & $(3.16)^{* * *}$ \\
\hline \multirow[t]{2}{*}{ Region 2} & 0.1500 & -0.3335 \\
\hline & $(1.04)$ & $(-2.82)^{* * *}$ \\
\hline \multirow[t]{2}{*}{ Region 3} & 0.3161 & -0.3883 \\
\hline & $(2.10) * *$ & $(-2.92)^{* * *}$ \\
\hline \multirow[t]{2}{*}{ Region 4} & -0.1036 & -0.2494 \\
\hline & $(-0.63)$ & $(-1.83)^{*}$ \\
\hline \multirow[t]{2}{*}{ Region 5} & 0.2984 & -0.7560 \\
\hline & $(1.91)^{*}$ & $(-5.30)^{* * *}$ \\
\hline \multirow[t]{2}{*}{ Constant } & -4.1008 & -2.8928 \\
\hline & $(-7.87)^{* * *}$ & $(-6.28) * * *$ \\
\hline
\end{tabular}

t-statistics in parentheses, $* * *$ significant at $1 \%$; $* *$ significant at $5 \%$; $*$ significant at $10 \%$ 
Appendix 2

Results of First-stage Probit Regressions to Obtain Inverse Mills Ratios

\begin{tabular}{|c|c|c|c|c|c|c|c|}
\hline \multirow[b]{2}{*}{ Variable } & \multicolumn{7}{|c|}{ Expenditure Category (Equation) } \\
\hline & Durables & Super-markets & Health & Education & Housing & $\begin{array}{l}\text { Invest- } \\
\text { ments }\end{array}$ & Other \\
\hline Log of Expenditure & $\begin{array}{c}0.4009 \\
(4.11)^{* * *}\end{array}$ & $\begin{array}{c}0.4587 \\
(5.71)^{* * *}\end{array}$ & $\begin{array}{c}0.2652 \\
(4.04)^{* * *}\end{array}$ & $\begin{array}{c}0.3020 \\
(4.10)^{* * *}\end{array}$ & $\begin{array}{c}0.5184 \\
(7.10)^{* * *}\end{array}$ & $\begin{array}{c}0.4749 \\
(7.00)^{* * *}\end{array}$ & $\begin{array}{c}0.4714 \\
(0.62)\end{array}$ \\
\hline Household Size & $\begin{array}{c}0.1174 \\
(2.14)^{* *}\end{array}$ & $\begin{array}{c}-0.1018 \\
(-2.35)^{* *}\end{array}$ & $\begin{array}{c}-0.0016 \\
(-0.05)\end{array}$ & $\begin{array}{c}0.7780 \\
(16.42)^{* * *}\end{array}$ & $\begin{array}{c}-0.0554 \\
(-1.48)\end{array}$ & $\begin{array}{l}-0.0579 \\
(-1.69)^{*}\end{array}$ & $\begin{array}{l}-2.6219 \\
(-1.84)^{*}\end{array}$ \\
\hline Number of children & $\begin{array}{l}0.0907 \\
(0.85)\end{array}$ & $\begin{array}{c}0.0071 \\
(0.10)\end{array}$ & $\begin{array}{c}0.2231 \\
(3.61)^{* * *}\end{array}$ & $\begin{array}{l}-0.1625 \\
(-2.45)^{* *}\end{array}$ & $\begin{array}{r}-0.0875 \\
(-1.39)\end{array}$ & $\begin{array}{c}0.0644 \\
(1.11)\end{array}$ & $\begin{array}{l}3.5640 \\
(1.90)^{*}\end{array}$ \\
\hline Age of Household head & $\begin{array}{c}-0.0145 \\
(-2.61)^{* * *}\end{array}$ & $\begin{array}{c}0.0010 \\
(0.19)\end{array}$ & $\begin{array}{c}-0.0014 \\
(-0.35)\end{array}$ & $\begin{array}{c}-0.0114 \\
(-2.42)^{* *}\end{array}$ & $\begin{array}{l}-0.0080 \\
(-1.79)^{*}\end{array}$ & $\begin{array}{c}-0.0016 \\
(-0.39)\end{array}$ & $\begin{array}{c}-0.1742 \\
(-1.44)\end{array}$ \\
\hline $\begin{array}{l}\text { Schooling of Household } \\
\text { head }\end{array}$ & $\begin{array}{c}-0.0046 \\
(-0.18)\end{array}$ & $\begin{array}{c}0.0549 \\
(2.86)^{* * *}\end{array}$ & $\begin{array}{c}-0.0066 \\
(-0.40)\end{array}$ & $\begin{array}{l}0.0323 \\
(1.68)^{*}\end{array}$ & $\begin{array}{l}0.0133 \\
(0.77)\end{array}$ & $\begin{array}{c}-0.0058 \\
(-0.35)\end{array}$ & $\begin{array}{r}0.0217 \\
(0.07)\end{array}$ \\
\hline $\begin{array}{l}\text { Number of household } \\
\text { members with six grades } \\
\text { of schooling }\end{array}$ & $\begin{array}{r}-0.0187 \\
(-0.26)\end{array}$ & $\begin{array}{c}0.1380 \\
(2.14)^{* *}\end{array}$ & $\begin{array}{c}0.0609 \\
(1.21)\end{array}$ & $\begin{array}{c}-0.4369 \\
(-7.27)^{* * *}\end{array}$ & $\begin{array}{c}0.0602 \\
(1.09)\end{array}$ & $\begin{array}{c}0.1043 \\
(2.07)^{* *}\end{array}$ & $\begin{array}{l}1.3187 \\
(1.64)\end{array}$ \\
\hline $\begin{array}{l}\text { Number of household } \\
\text { members with nine } \\
\text { grades of schooling }\end{array}$ & $\begin{array}{c}-0.1009 \\
(-1.01)\end{array}$ & $\begin{array}{l}0.1315 \\
(1.77)^{*}\end{array}$ & $\begin{array}{c}-0.0472 \\
(-0.76)\end{array}$ & $\begin{array}{c}-0.4769 \\
(-6.55)^{* * *}\end{array}$ & $\begin{array}{c}0.0043 \\
(0.07)\end{array}$ & $\begin{array}{c}0.2068 \\
(3.31)^{* * *}\end{array}$ & $\begin{array}{l}2.4203 \\
(1.63)\end{array}$ \\
\hline $\begin{array}{l}\text { Number of household } \\
\text { members with ten or } \\
\text { more grades of }\end{array}$ & & & & & & & \\
\hline schooling & $\begin{array}{l}0.0490 \\
(0.38)\end{array}$ & $\begin{array}{l}0.0248 \\
(0.30)\end{array}$ & $\begin{array}{c}0.0613 \\
(0.79)\end{array}$ & $\begin{array}{c}-0.2555 \\
(-2.83)^{* * *}\end{array}$ & $\begin{array}{l}-0.1636 \\
(-1.95)^{*}\end{array}$ & $\begin{array}{c}0.2141 \\
(2.65)^{* * *}\end{array}$ & $\begin{array}{c}0.0395 \\
(2.17)^{* *}\end{array}$ \\
\hline Landholdings & $\begin{array}{c}0.0084 \\
(0.68)\end{array}$ & $\begin{array}{l}-0.0107 \\
(-2.04)^{* *}\end{array}$ & $\begin{array}{c}-0.0058 \\
(-1.17)\end{array}$ & $\begin{array}{l}0.0031 \\
(0.70)\end{array}$ & $\begin{array}{c}0.0001 \\
(0.02)\end{array}$ & $\begin{array}{c}0.0310 \\
(3.54)^{* * *}\end{array}$ & $\begin{array}{c}0.1734 \\
(0.66)\end{array}$ \\
\hline Frequency of Transport & $\begin{array}{l}0.0246 \\
(1.71)^{*}\end{array}$ & $\begin{array}{c}0.0468 \\
(4.17)^{* * *}\end{array}$ & $\begin{array}{c}0.0253 \\
(2.85)^{* * *}\end{array}$ & $\begin{array}{l}0.0227 \\
(2.19)^{* *}\end{array}$ & $\begin{array}{l}0.0161 \\
(1.71)^{*}\end{array}$ & $\begin{array}{r}0.0081 \\
(0.93)\end{array}$ & $\begin{array}{c}0.1514 \\
(1.05)\end{array}$ \\
\hline $\begin{array}{l}\text { Inaccessibility During } \\
\text { Weather Shocks } \\
\text { (Dummy) }\end{array}$ & $\begin{array}{c}-0.2413 \\
(-1.06)\end{array}$ & $\begin{array}{c}0.0656 \\
(0.32)\end{array}$ & $\begin{array}{c}-0.0604 \\
(-0.40)\end{array}$ & $\begin{array}{r}-0.2577 \\
(-1.47)\end{array}$ & $\begin{array}{c}-0.1030 \\
(-0.62)\end{array}$ & $\begin{array}{l}-0.1805 \\
(-1.21)\end{array}$ & $\begin{array}{r}-0.1661 \\
(-0.80)\end{array}$ \\
\hline International Migration & & & & & & & \\
\hline Probability $(\mathrm{p} 1)$ & $\begin{array}{l}-7.9771 \\
(-1.77)^{*}\end{array}$ & $\begin{array}{c}12.8876 \\
(2.88)^{* * *}\end{array}$ & $\begin{array}{c}-0.6848 \\
(-0.18)\end{array}$ & $\begin{array}{c}8.2183 \\
(2.04)^{* *}\end{array}$ & $\begin{array}{c}2.8392 \\
(0.72)\end{array}$ & $\begin{array}{c}-12.3545 \\
(-3.12)^{* * *}\end{array}$ & $\begin{array}{c}-78.4101 \\
(-1.07)\end{array}$ \\
\hline Log of Expenditure * p1 & $\begin{array}{c}0.5543 \\
(1.54)\end{array}$ & $\begin{array}{l}-0.6526 \\
(-1.80)^{*}\end{array}$ & $\begin{array}{c}-0.0198 \\
(-0.06)\end{array}$ & $\begin{array}{c}-0.1037 \\
(-0.31)\end{array}$ & $\begin{array}{c}-0.4376 \\
(-1.36)\end{array}$ & $\begin{array}{c}0.7860 \\
(2.43)^{* *}\end{array}$ & $\begin{array}{c}8.2587 \\
(1.26)\end{array}$ \\
\hline
\end{tabular}




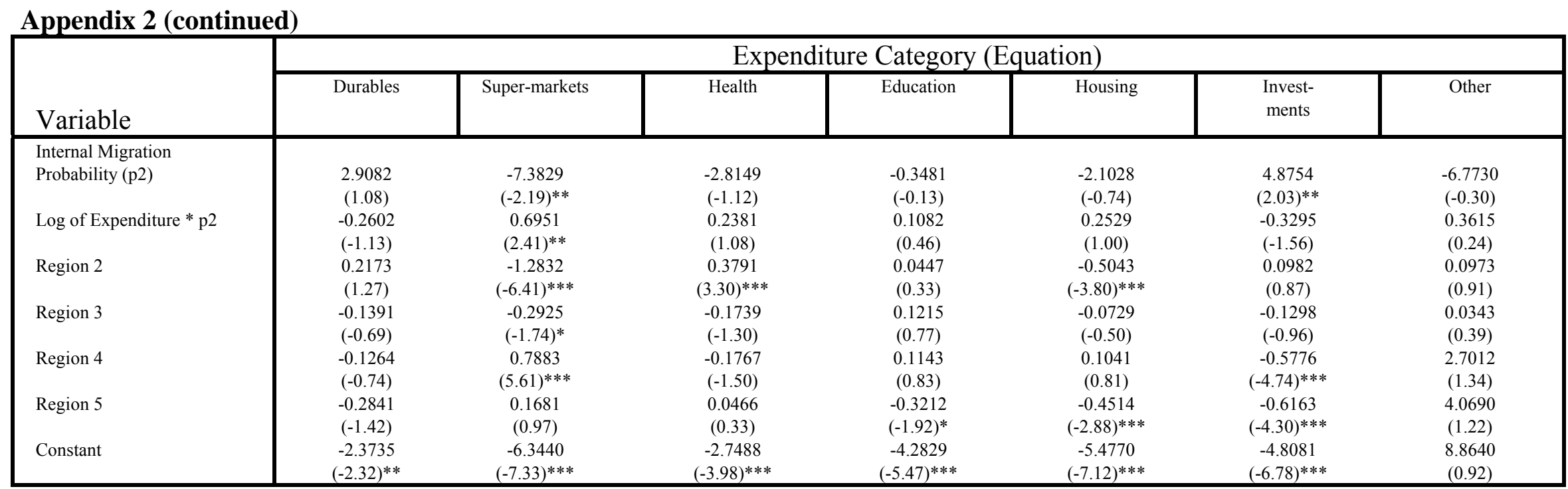

t-statistics in parentheses, ${ }^{* * *}$ significant at $1 \%$; ** significant at $5 \% ; *$ significant at $10 \%$ 